\title{
CHRISTIAN TORAJAN YOUTH IN PERCEIVING ALUK TO DOLO
}

\author{
Erin Gayatri \\ Centres for Religious and Cross-Cultural Studies, Gadjah Mada University \\ Email: gayatri.erin@yahoo.co.id
}

\begin{abstract}
The fascinating influence of world religion has given important impact to the existence of indigenous religion such as Aluk To Dolo within the life of the Christian Torajan Youth who live in Yogyakarta. Aluk To Dolo as one of indigenous religions in Indonesia, in fact, is almost in the position of weak as its followers are decreasing in its region of origin, Tanah Toraja of Sulawesi. It is found that only one leader is still remaining in Toraja accompanied by the practice of Rambu Solo which is also still being maintained in the region. This work is based on the view of the youth toward Alok To Dolo as the youth play an important role to determine and negotiate the inheritance of their religion including indigenous religion within their life. This article examines how Christian Torajan Youth perceive Christianity and Aluk To Dolo. Data collection is conducted through depth interview and focused group discussion with a group of Christian Torajan Youth members who stay in Yogyakarta for their studies. They are affiliated to Torajan student organizations and Torajan tribal church in Yogyakarta. This work concludes that Torajan students perceive the Aluk To Dolo as pendamping agama or the companion of religion they practice (Christianity) besides perceiving it as their cultural home base. In other words, they mean the Aluk To Dolo for cultural practices supporting their Christianity practice in their life. It is also found that the decreasing of the practice of Alok To Dolo by the students is more caused by three factors including the distance to the origin land, the influence from the Toraja tribal church, and the literatures having influence in their believe. As student, although the Christian Torajan youth are close and more influenced by literatures in Christianity (church), they also practice the teachings of the local religion to keep their cultural identity.
\end{abstract}

Keywords: Torajan, Christianity, Youth, Aluk To Dolo, Domination, Church

\section{INTRODUCTION}

Some layers of identity have shaped people for a long time through generations. Culture and religion as part of identity elements are also flux into identity formulation process (Barbara Stark in Kymlicka and Norman 2000, 199). Therefore, every generation will always bring those elements as its characteristic. The transformation process of identity heavily depends 
on how the verbal and nonverbal communication are done within a certain community. In a verbal way, people use the writing and oral communication. This way is inherited to the portion of identity which contains culture and religion in the idea and thought. In a nonverbal setting, people use gestures, body language, symbols, dialeg, intonation and so forth. This long process influences culture and religion resulting the interwoven threads which is difficult to be re-unraveled. Regarding from where the influence of culture and religion comes from, it seems like the everlasting complexity of hybridity around the people within the community.

Indeed, people would commonly attempt to look for their authenticity within the culture or religion. In many cases, the level of culture and religion in one community hasto be debated: which one is part of the culture and which one is part of religion. The perenialistic philosophy suggests that culture is the medium and the space for religion to enter into the society (F. Schuon, 1976). How the guidance from the esoteric one turns into ecsoteric other. However, religion itself formulates culture among the human and non-human later. It has drawn us to the encounter between culture and religion. Furthermore, it is interesting to see the encounter between religion (indigenous) and religion (world religion) where those have interwoven with particular culture in the previous particular religion.

As the phenomenon in the world, the encounter between indigenous religion and world religion negotiates each other. In the particular region of South Sulawesi, many narratives provide the history of indigenous religion encounter with a world religion. For instance, the early belief of Buginese-Makassarese encountered with Islam, Ammatoan encountered with Islam, and the early belief of Torajan encountered with Christianity and so forth. Hence, those phenomenon result some kind of conditions that show how the process of negotiating between indigenous religion and world religion was run. The scholars use terms of complementary, contestation, syncretism, persistent, and intermingle to explain the result of the encountering. Some diversities of conditions such as many Bissues in the palaces of South Sulawesi have been killed for the political (feodal) and religious reason (infidel) (Pelras 2006, 339). Ammatoan people who were Muslim in animistic ways, whi practice Islamic teachings, but they never leave their local traditional belief called Patuntung (Samsul Maarif, 2014). We can see it in the way they treat the nature using Patuntung. In some forests, there is particular time to visit it and take the natural resources as enough as for their needs. Further, they keep the concept of God, Patuntung, in their everyday rituals. The Ammatoan does not try to contrast and problematize between Islam and Patuntung instead of harmonize 
them. Probably one of the reason is because the Ammatoan region is quite safe from the modernization which influences Toraja regions as the favourite tourism destination.

The Christianity in Toraja also has resulted a scholar of theology there who has big influence among the Christian people in Toraja towards their local belief. Conversely, Javanese Muslim who doing Islam and Kejawen concomitantly create the particular character of Islam in Indonesia (C. Geertz 1960; Woodward 1988; A. Beatty 1996; Hilmy 1998; M. Khusen 2005; Suwito 2007). Commonly, in the case of Islam Kejawen, people practise such -the offering to the nature or what they perceive as the spirit around them, while Islam has shaped them in some ways. People who practice Islam Kejawen in Yogyakarta do not need to feel threaten for being Muslim Kejawen as long as the Sultan and Kraton still practice many rituals as the inheritance of their ancestor. Hinduism in Bali has its own concept which considering three important aspects of relation between Hinduism and local tradition. The concept is called Desa Kala Patra, meaning place, time, and condition. Scientifically this concept is highly inclusive and tolerance. Those three words portray the principle of Hinduism in viewing the local tradition in a particular place, time, and condition. It is not wondering why Hindu Bali does not try or force itself to be similar with the Hindu India's characteristic. Almost the ritual of Hindu Bali is the assimilation process between Hinduism and traditional local belief there. Therefore, Michel Picard (1997) stated that we could not deny that Hindu has been characterized, yet it is too narrow to say that Bali is merely Hindu because the traditional local belief has a big portion in Bali. .

Some of Indonesian scholars has studied about the process of dialogue between world religions, national politics, and indigenous religion (Atkinson, 1983; Kipp and Rodgers, 1987). They presented how the construction of religion in Indonesia is determined by political consensus and the domination of world religions. For example, the redefinition of Sumbanese spirit worship as a "religion" came from the Christianity church and Indonesian government for a tourism reason (Atkinson, 1983 ; Scarduelli, 2005). M. Adams (1993, 55) has examined how indigenous and Christian notions not only coexist but intermingle and at times compete in the Christian Torajans. In this paper, I attempt to see how youth Christian Torajans perceive both the indigenous and Christianity notions today. What I mean as Youth Christian Torajan here is a group of students from the descendent of Torajan tribe. Their age is between 19-23 years old, and Christianity is their religious faith. My concern is the youth Christian Torajans who study in Yogyakarta where they interact with the other cultures and conditions that probably affect their perspective on 
Aluk To Dolo and Christianity ${ }^{1}$. Discussing the encounter between indigenous religion and world religion can lead us to see how the state treats and polarizes official religions and traditional local beliefs. That negotiation arrived and used in youth perspective of religion and local tradition. I wonder how if people who were affiliated to indigenous religion or penghayat kepercayaan can mention their belief in the identity card earlier, probably they who declare their traditional local belief will not feel threatened. For example, Suku Anak Dalam in Jambi who has converted to Islam because they do not have any choice, they have to convert to Islam for send their children into school and get subsidy from government. They have lost their livelihood because the forest where they live becomes oil palm plantation now. I decide to choose Youth as the subject of this paper because they become the starting point in seeing the continuity or dis-continuity of a religion and tradition. They are challenged in threating their - local tradition which has been internalized and their new modern world that could not be avoided. For instance the Suku Anak Dalam tribe have to break some mores in order to get the modern education outside their region. However, I have to underline that the matters between Aluk To Dolo and Christianity have to be considered in the first time in the encountering between both religions. Meanwhile, as the third generation of Christian Torajans, they face different discussion from the first encountering.

\section{THE ENCOUNTER BETWEEN ALUK TO DOLO AND CHRISTIANITY}

The early Toraja has been limited to the lowland of politic, culture, and religion, even though Toraja has the relative relation to Luwu that has maintained a kingdom. Toraja and Luwu have the same idea about To Manurun ancestor, yet different in some terms (Waterson 2006, 70). In the beginning, Torajan totally has hold Aluk To Dolo (The ways of the ancestors) religion. It has guided the Torajan in their way of life. M. Adams (1993) argued that indigenous religions in insular Southeast Asia are oriented towards practice than philosophy. Therefore, when people want to understand the Aluk To Dolo religion, it has to be understood through their rituals. In the sense of Aluk To Dolo, Torajan practices two kinds of rituals such as Rambu Tuka' (rituals of life) and Rambu Solo (death rituals). In the past, those rituals have depended on the social strata. The higher the strata, the higher is the cost of ritual. However, now it has been shifted, as it is more determined by the economic resources like a migration of

${ }^{1}$ This article is based on interview and group discussion data conducted in Yogyakarta with the a group of Youth Christian Torajans (Gerardo, Davis, Devi and Hedwik) who affiliate in the Torajan Students Forum in Yogyakarta. Two of them (Devi and Hedwik) were born and raised in Kalimantan which is mean that they are descendent of Torajan but live in the different culture. While Gerardo and Davis were born and raised in Toraja. 
Christian Torajan who send their money for ritual needs (Volkman 1979, 1).

Dutch colonialism came to Toraja in 1905, then in 1913 Christianity entered to the Toraja through the first missionary namely Rev. A.A. van de Loosdrecht ${ }^{2}$. A form of proselytising by the Dutch missionaries in Toraja is by underlying the similarities of Christianity and Aluk To Dolo. They drew a parallel view between Christian and Torajan beliefs. They depicted the God of Christianity and Puang Matua as the creator figure of Toraja mythology by same structures. Other efforts to persuade the Torajan in order to convert to Christianity were through education, employment and prestige (Bigalke 1981, 152).

Finally, Christianity has come to Toraja for a century, and $90 \%$ of Torajan has converted to the Christianity, $5 \%$ still has been affiliated to Aluk To Dolo, and 5 percent has been Muslims (John Liku-Ada' 2014, 180). However, I want to underline that it is quite difficult to categorise Torajan who is no longer doing Aluk To Dolo rituals, Torajan who is still doing some part of rituals, or Torajan who is still totally applying Aluk To Dolo in their life. Based on the interview and group discussion with the youth Christian Torajan, people who have converted to the Pentecostalism are forbidden to do the ritual neither Rambu Tuka' nor Rambu Solo (contestation model). Whereas, Torajan who hold Protestantism and Catholic are allowed to do both rituals, yet they are forbidden to do gambling in the silaga ${ }^{3}$ and sibitte 4 as part of the ritual process (intermingle or complementary model). In the contestation and complementary model, Torajan faces two different demands: what is ordered and disordered in Aluk To Dolo and Christianity. Then, people who totally still hold Aluk To Dolo mostly live in the forest (pangngala') in which they are more than $5 \%$ from all the total of population in Toraja (persistent model). Today, the religious leader of Aluk To Dolo is the only one called Ne' Tato' Dena'.

According to religiosity of Torajan above, first I argue that it can be different between the encounter of indigenous religion and world religion, the purposes of colonialism, and proselytising suggested by the government rules particularly about identity card or public administration matters. Virtually, in 1969 Aluk To Dolo has been recognised as official religion affiliated to Hinduism (M. Adams 1993, 56). When I interview Gerardo, he explained that he has seen his aunty who has Hinduism religion in her identity card, yet only she practices Aluk To Dolo in her daily life. That event shows that there is no significant debate -when Torajan at that time has used Hinduism only

${ }^{2} \mathrm{He}$ was killed at the age of 32 years and buried in Toraja Land, 1917. Many perspectives came to explain why he was killed. Church and Torajan believe that it was because some people ban missionaries who offer new religion in Toraja.

${ }^{3}$ Silaga is compete the buffalo

${ }^{4}$ Sibitte is compete for the chicken 
for administration purposes. It was similar with the case of Ammatoan who still holds their traditional belief while the government recognizes them as the Muslim especially in the census matter. In Maarif (2014, 151), Ammatoan does not has such controversy between Islam and Patuntung among them, as Maarif explained both are complementary and all-encompassing each other.

\section{CHRISTIAN TORAJAN YOUTH IN PERCEIVING ALUK TO DOLO AND CHRISTIANITY}

Recently in 2013, Christian Torajan and other Christians celebrated a century of gospel in Toraja. It has reflected how the relation between Aluk to Dolo and Christianity to date. Related to the people that I have interviewed, all of them are the third generations of Christian Torajan. It means that their grandmothers and grandfathers have converted into Christianity when they were young. Christian Torajan Youth is a group of students consisting of the descendent of Torajan people. They are aged around 19-23 year old holding Christianity as their religious faith. Gerardo told me that his grandfather has become local missionary incorporating with the Dutch missionaries. However, his grandfather in that time has had an important role in Aluk To Dolo rituals. Therefore, he has still inherited insights of Aluk To Dolo from his family and the environment in Toraja when people doing the rituals. Gerardo fluently has explained what Aluk To Dolo through the meaning of every part of the ritual. He stated that people who want to understand what Aluk To Dolo is, they can join prominently the ritual of Rambu Solo. It is because through the ritual, Torajan relates to their ancestor who will be To Membali Puang and grace of their descendent. Broadly, the cosmology of Torajan is explained in their rituals. Until today, Gerardo still believes that Aluk To Dolo is his ancestor religion and he has to inherit it to his generations. After his death, his generations must do Rambu Solo ritual for him. Virtually he got confused when he can relate between Puya and heaven, or Puang Matua and God. He said, one day there has been a Pastor who has attempted to explain that Puya is not the last destiny of Christian Torajan. People have to reach the heaven after arrived in Puya. Gerardo told that he does religious activities both in Aluk To Dolo and Christianity. He does not problematize where they will arrived after death, even though other people problematize it as duality. Interestingly, Gerardo the only informant who strictly will maintain the ritual of Rambu Solo. It has related to the social strata in Toraja where Gerardo has the highest social strata called Puang (dignity).

Importantly, when Gerardo still believes Aluk To Dolo as religion, Davis, Devi and Hedwik perceive Aluk To Dolo as the culture or religious companion 
(pendamping agama). When they mention term "agama", they always refer to Christianity as the world religion instead of Aluk To Dolo. They are more influenced by the values and thoughts of Christianity. They "rationalize" the reason why they should not totally believe the mythology of Aluk To dolo. Devy and Hedwik, born and raised in Kalimantan, the more know about Toraja and Aluk To Dolo after joining Torajan Student Forum. One of the reasons that they asserted is how the number of buffalo sacrificing can determine whether people are easier or more difficult to reach Puya or heaven. How about the good deeds and bad deeds of people which should be the main factor of people go to the hell or heaven. In the ritual of Rambu Solo, they will not force their families or generations to do it for them after death. Many cases has proved that ritual of Rambu solo has forced and burdened the family for the costs of the ritual. Moreover, after Rambu Solo ritual, the family has many debts because all of the animal and the other things that people bring to the ritual are counted as debts. When the family could not return the same gifts one day, they will be ashamed (siri') in the society. When the family have not yet had enough money, the death body is only assumed as To Makula (the one who has fever) (Tsinjilonis 2000, 5), so that the family only focuses to collect the many for the ritual. One of the books written by the descendent of the Torajan (father) and Dutch (mother) who born and raised in Jakarta city, he has criticised the demand of customary law for him and his family in Toraja where they have to do Rambu Solo ritual with the high costs as a form of honour to his father who has the high social strata in Toraja (Saroengallo, 2008). Pragmatically, he did not live with that customary law and have to obey it. Suddenly, it is difficult for him to unite his modern perspective and his status as the descendent of Torajan whose high social strata.

\section{THE DISCOURSE BETWEEN ALUK TO DOLO AND CHRISTIANITY}

When I asking those students what does it mean to be a Torajan? They responded that to be Torajan they should have three principles: smart (manarang), brave (barani), and rich (sugi). Those principles originate from the ancestor, and those are in line with the ritual of Aluk To Dolo virtually. Indirectly, they argue that Torajan cannot be separated from Aluk To Dolo. However, usually people perceive that Aluk To Dolo is merely Rambu Tuka' and Rambu Solo while many values and the way of life of Torajan regularly has been disappeared from Torajan. In addition, they are affiliated to Torajan Student Forum (IKAPMAJAYA; Ikatan Keluarga Pelajar Mahasiswa Toraja Yogyakarta) where they can learn each other about the identity of Torajan. In addition, they are affected by the environment of Yogyakarta as the city of education. They meet new people and new cultures that lead to reflection of 
their identity as Torajan. They are demanded to contextualize Aluk To Dolo today. The youth Christian Torajan does not want to lose Aluk To Dolo in their life, but they want to reform some of rituals which are no longer relevant in the modern society, such the high cost of Rambu Solo.

Through the third generations of youth Christian Torajan, it can be seen how the discourse that they got to understand and perceive Aluk To Dolo and Christianity can be a starting point why they tend to be influenced by Christianity and Aluk To Dolo in their life. Firstly, Aluk To Dolo is only practiced in Toraja whereas Youth Christian torajan in Jogja is in distance from Toraja. Thus, there is discontinuity of Aluk To Dolo in which it has the risk whether it still has the space in Youth Christian torajan in Yogyakarta or not. Moreover, Devy and Hedwik who were born and raised in Kalimantan have twice risk even though they always come to Toraja when their family holds some events. Secondly, Toraja has the tribal church (Gereja Kristen Toraja) which is the second largest tribal church after HKBP (Huria Krsiten Batak Protestan). One of the churches is located in Yogyakarta where almost Youth Christian Torajan worship there and are affiliated to that church community. Their environment is mostly shaped by Christianity that affects their belief. Thirdly, as the student, Youth Christian Torajan interact with religious texts/ literatures that mostly provided by texts of Christianity. Gerardo mentioned two interesting books namely Reinterpretasi \& Reaktualisasi Budaya Toraja: Refleksi Seabad Kekristenan Masuk Toraja (Reinterpretation \& Reactualization of Toraja Culrute: Reflection of a century Christianity in Toraja) and Aluk To Dolo Menantikan Kristus: Ia Datang agar Manusia Mempuanyai Hidup dalam Segala Kelimpahan (Aluk To Dolo Waiting for Christ: He Comes so that Human live in Abundance). Briefly, those books represent the discourse about how Aluk To Dolo is a less or incomplete religion, then Christianity comes in order to complete it. Relate to that kind of discourse, people are regardless how Torajan applied Aluk To Dolo in their everyday life. Through the world religion's perspective, people have determined what is appropriate to be called religion and culture or local practice (Huston Smith, 2006).

From those books I found some narratives that portray Aluk To Dolo and Christianity in two opposite sides. There is a new statement why Rambu Solo has been allowed by the missionaries in the past is because Torajan deeply internalise the ritual and it would be the obstacle for the spreading of Christianity if the missionaries banned it. Furthermore, some subtitles in the second book above such as Masalah Agama dan Transendensi Mutlak (Liku-AdA' 2014, 130) which problematize how Torajan make the creator (Puang Matua) less-transcendent in that idea because they depicted God very 
anthropomorphically. In this case, the Western context about supernatural always does the dichotomy between the natural and supernatural (M. Jindra, 2003;M. Klass, 1995). In addition, the subtitle Alukta Bukanlah Ritual explains that Aluk To Dolo is the universal truth which is in accordance with Christianity and does not need ritual virtually. Also, there is no contrast between religion and culture. Whereas as I mentioned above that to understand Aluk To Dolo we have to understand its ritual. The other term which underlines the opposite between Christianity and Aluk To Dolo is within subchapter of Aluk To Dolo versus Christianity in the first book. Briefly, in a century when Christianity has come to Toraja, the church states that Aluk To Dolo especially Rambu Solo is problematic because the value of Rambo Solo has shifted from harmonisation to the prestige and wealth. I have argued before that through the world religion perspective, the church only assesses Rambu Solo as the representation of Aluk To Dolo and ignores the other values in the everyday religion of the Torajan because Rambu Solo is only hold when a Torajan dies. The church has to find other concept of Rambu Solo as a replacement of the role of Aluk To Dolo in doing Rambu Solo because the Pastor only involve it in the pray time (Bert Tallulembang 2012, 96).

Asthesamecasein North Sumatera, Karopeoplewhodorituals andgiveofferings to the Sinabung mountain are perceived as an infidel by the church. Moreover, they are punished by not to practise it anymore. Importantly, some cases have indicated that there has been shifting ideas in the concept of inculturation and contextualisation in Christianity in which it did not problematize some rituals that people do in the past. Then, gradually Christianity reduce that traditional local belief especially in the rituals as the way of people expresses their belief. Tanudjaja (200) portrays that contextualisation is a mission strategy to invite local people attention and thought that there is no contrast between their local traditional belief and Christianity. Meanwhile, Bajo people who practice Islam and sea religion ${ }^{5}$ can express both in a ritual. When Bajo people give the offering to Mba Mo Dilao, they start with praying "basmalah" as the influence of Islam. However, a problem comes from the people in the land outside Bajo people and the government. They perceive Bajo as doing shirk, superstition, polytheist in practice (Baskara, 2016). Thus, the government has suggested Muslim preacher to guide Bajo people to purify their Islam and advise gradually to leave their traditional local belief. In addition, similar to Toraja, mostly the rituals in Bajo people become the commodity of tourism. So, the

\footnotetext{
${ }^{5}$ Sea religion or agama laut is a concept for Bajo people who live on the sea and believe that the reincarnation of their ancestor named Mbo Ma Dilao have a big power and keep the sea. Bajo people doing sea nomads where for particular time they move from one to the other place in the sea.
} 
question is whether the rituals are practiced because of their traditional local belief or merely for the tourism demands.

\section{CONCLUSION}

Religion is a journey. The religiosity of a person is determined by where he/she was born and raised and where he stands now. The encounter between Aluk To Dolo and Christianity is resulted from three models: contestation where some rituals in Aluk To Dolo are forbidden, complementary where the church is also involved in Rambu Solo ritual, and persistent where a little number of Torajan still totally believes and practices Aluk To Dolo in their life. Four youth Christian Torajans who study in Yogyakarta tend to leave the ancestor religion, Aluk To Dolo, and consider it as a culture. The only reason I found why youth Torajan who was born and raised in Toraja still believes and wants to continue Aluk To Do in their life because of the high social strata that they have. When youth Christian Torajan leaves Toraja to study in Yogyakarta, there has been a shifting idea in the way they perceive religious matters. Yogyakarta provides Christianity environment more widely which leads the youth Christian Torajan to be more active in the Torajan Christian church. As a student, Youth Christian Torajan is more rational in the way they perceive Aluk To Dolo and Christianity. The discourse and discussion about those religions are more influenced by Christianity that sees Aluk To Dolo through world religion perspective in which the concept of God, spirituality, heaven and mystic have to be an essence and not merely a function. Youth Christian Torajan demands to reform the Rambu Solo ritual from the high costs to be more economical. Moreover, some of them do not want to be buried using Rambu Solo ritual because it will burden their family later. However, many values or the way of life of Torajan in Aluk To Dolo need more inquiries, because Aluk To Dolo is not only about Rambu Tuka' and Rambu Solo.

\section{BIBLIOGRAPHY:}

Adams, K. M. (1993). The discourse of souls in Tana Toraja (Indonesia): indigenous notions and Christian conceptions. Ethnology, 32(1), 55-68.

Baskara, B. (2016). Islam Bajo Agama Orang Laut: Yogyakarta. Javanica.

Beatty, A. (1996). Adam and Eve and Vishnu: Syncretism in the Javanese slametan. Journal of the Royal Anthropological Institute, 271-288.

Bigalke, T. W. (1981). A Social History of “Tana Toraja"1870-1965. Unpub lished 
$P h D$ (Doctoral dissertation, thesis, University of Wisconsin-Madison, Ann Arbor microfilms).

Christou, M. (2006). An Ethnographic Interpretation of the Smoke Rising and Smoke Descending Ceremonial Attire of the Sadan Malimbong Toraja: University of Nebraska. Lincoln.

Geertz, C., Mahasin, A., \& Rasuanto, B. (1983). Abangan, santri, priyayi: dalam masyarakat Jawa (No. 4). Pustaka Jaya. Jakarta.

Hilmy, M. (1998). Cultural acculturation of Javanese Islam: A critical study of the slametan ritual. Al-Jamiah, 12(62).

Jindra, M. (2003, November). Natural/supernatural conceptions in Western cultural contexts. In Anthropological Forum (Vol. 13, No. 2, pp. 159166). Taylor \& Francis Group.

Khusen, M. (2005). Contending Identity in the Islamic Ritual: the Slametan among Surinamese Javanese Muslims in the Netherlands. Al-Jamiah: Journal of Islamic Studies, 43(2), 283-308.

Kymlicka, W., \& Norman, W. J. (Eds.). (2000). Citizenship in diverse societies. Oxford: Oxford University Press.

Liku-Ada, J. (2014). Aluk To Dolo Menantikan Kristus. Yogyakarta: Gunung Sopai.

Maarif, S. (2014). Being a Muslim in Animistic Ways. Al-Jamiah: Journal of Islamic Studies, 52(1), 149-174.

Morton, K. (1995). Ordered Universes: Approaches to the Anthropology of Religion. Oxford: Oxford University Press.

Pelras, C., Abu, A. R., \& Arsuka, N. A. (2006). Manusia Bugis. Nalar: Forum Jakarta-Paris: École Française d'Extrême-Orient (EFEO).

Saroengallo, Tino. (2008) Ayah anak, beda warna!: anak Toraja kota menggugat: Jakarta. Tembi.

Picard, M. (1997). Cultural tourism, nation-building, and regional culture: The making of a Balinese identity. Tourism, ethnicity, and the state in Asian and Pacific societies, 181-214.

Scarduelli, P. (2005). Dynamics of Cultural Change among the Toraja of Sulawesi. The Commoditization of Tradition. Anthropos, 389-400.

Schuon, F. (1999). Language of the Self. World Wisdom Books.

Smith, H. (2007). A seat at the table: Huston Smith in conversation with Native Americans on religious freedom. Univ of California Press. 
Suwito, N. S. (2007). Slametan dalam Kosmologi Jawa: Proses Akulturasi Islam dengan Budaya Jawa in Jurnal Ibda. Purwokerto: P3M Stain Purwokerto.

Tallulembang, B. (2012). Reinterpretasi \& Realtualisasi Busaya Torajai: Refleksi Seabad Kekristenan Masuk Toraja. Yogyakarta: Gunung Sopai.

Tangdilintin, L. T. (1978). Toraja dan kebudayaannya: Kantor Cabang II Makassar, Lembaga Sejarah \& Antropologi.

Tanudjaja, R. (2000). Kontekstualisasi sebagai Sebuah Strategi dalam Menjalankan Misi: Sebuah Ulasan Literatur. Veritas 1/1, 19-27.

Tsintjilonis, D. (2000). Death and the sacrifice of signs:'measuring'the dead in Tana Toraja. Oceania, 71(1), 1-17.

Volkman, T. (1979). The riches of the undertaker. Indonesia, (28), 1-16.

Woodward, M. (2010). Java, Indonesia and Islam (Vol. 3). Springer Science \& Business Media. 